\title{
PELAKSANAAN KONTRAK KERJA TERHADAP PEKERJA KONTRAK \\ DENGAN PIHAK RUMAH SAKIT UMUM DAERAH WANGAYA KOTA DENPASAR
}

\author{
OLEH : \\ I Gusti Ketut Bagusdharma Liran* \\ I Nyoman Bagiastra** \\ Fakultas Hukum Universitas Udayana \\ Program Kekhukusan Hukum Bisnis
}

\begin{abstract}
ABSTRAK
Upah bagi para pekerja merupakan faktor penting karena merupakan sumber untuk membiayai dirinya dan keluarganya dan bagi tenaga kerja yang berpendidikan upah yang merupakan hasil investasi sumber daya manusia pada dirinya dan bagi para kelompok tertentu upah melambangkan status sosial dan penghargaan bagi pekerja. Berdasarkan Undang-Undang Ketenagakerjaan Nomor 13 Tahun 2003 menyatakan "setiap pekerja atau buruh berhak memperoleh penghasilan untuk memenuhi kehidupan yang layak bagi kemanusiaan".

Tujuan penelitian ini adalah untuk mengetahui standar dalam memberikan upah minimum terhadap pekerja kontrak di Rumah Sakit Umum Daerah Wangaya Kota Denpasar dan pelaksanaan upah minimum terhadap pekerja kontrak di Rumah Sakit Umum Daerah Wangaya Kota Denpasar. Metode penelitian yang digunakan adalah penelitian hukum empiris yaitu penelitian ilmiah yang dilakukan dengan melihat kesenjangan teori dan praktek.

Berdasarkan hasil penelitian yang dilakukan terhadap permasalahan dapat disimpulkan bahwa standar dalam memberikan upah minimum terhadap pekerja kontrak di Rumah Sakit Umum Daerah Wangaya Kota Denpasar mengacu kepada keputusan Direktur Rumah Sakit Umum Daerah Wangaya Kota Denpasar Nomor 188.45/14/RSUDW/2016 Tentang Penetapan Gaji Pegawai Non Pegawai Negeri Sipil (PNS) pada Rumah Sakit Umum Daerah Wangaya Kota Denpasar Tahun 2016 dan pelaksanaan upah minimum terhadap pekerja kontrak di Rumah Sakit Umum Daerah Wangaya Kota Denpasar tidak sesuai dengan Peraturan Menteri Tenaga Kerja dan Transmigrasi Nomor 7 Tahun 2013 Tentang Upah Minimum dan Peraturan Walikota Denpasar Nomor 4 Tahun 2014 Tentang Pedoman Pengangkatan dan Pemberhentian Pejabat Pengelola dan Pegawai Non Pegawai Negeri Sipil Pada Rumah Sakit Umum Daerah Wangaya Kota Denpasar.
\end{abstract}

Kata Kunci : Kontrak Kerja, Upah Minimum

\section{ABSTRACK}

Wages for workers are an important factor because they are a source of financing for themselves and their families and for workers with a wage

\footnotetext{
* I Gusti Ketut Bagusdharma Liran adalah Mahasiswa Fakultas Hukum Universitas Udayana, korespondensi dengan penulis melalui Email : igustiketutbagusdharma@gmail.com

** I Nyoman Bagiastra adalah Dosen Fakultas Hukum Universitas Udayana.
} 
education which is the result of investment in human resources for themselves and for certain groups wages symbolize social status and respect for workers. Based on the Manpower Act Number 13 of 2003 states "every worker or laborer has the right to earn income to fulfill a life that is worthy of humanity".

The purpose of this study was to determine the standard in providing minimum wages to contract workers at the Wangaya Regional General Hospital in Denpasar City and the implementation of the minimum wage against contract workers at the Wangaya Regional General Hospital, Denpasar City. The research method used is empirical legal research namely scientific research conducted by looking at the gap between theory and practice.

Based on the results of research conducted on the problem it can be concluded that the standard in providing minimum wages to contract workers at the Wangaya Regional General Hospital in Denpasar City refers to the decision of the Director of the Wangaya Regional General Hospital of Denpasar Number 188.45 / 14 / RSUDW / 2016 concerning the Determination of Non Employee Salaries Civil Servants (PNS) at the Wangaya Regional General Hospital of Denpasar City in 2016 and the implementation of the minimum wage against contract workers at the Wangaya Regional General Hospital in Denpasar City is not in accordance with the Minister of Manpower and Transmigration Regulation No. 7 of 2013 concerning Minimum Wages and Denpasar Mayor Regulation No. 4 of 2014 concerning Guidelines for Appointment and Dismissal of Management Officers and Non-Employee Employees Civil Affairs at Wangaya Regional General Hospital, Denpasar City.

\section{Keywords: Work Contract, Minimum Wage}

\section{Pendahuluan}

\subsection{Latar Belakang}

Berdasarkan Undang-Undang No. 13 tahun 2003 tentang ketenagakerjaan bahwa pembangunan nasional dilaksanakan dalam rangka pembangunan nasional dilaksanakan pembangunan manusia Indonesia seutuhnya dan pembangunan masyarakat Indonesia seluruhnya untuk mewujudkan masyarakat yang sejahtera, adil, makmur, yang merata, baik materiil maupun spiritual berdasarkan pancasila dan Undang-Undang Dasar Negara Republik Indonesia Tahun 1945. Di Indonesia sendiri sumber hukum perusahaan di atur dalam KUHD, Peraturan perundang-undangan yang berkaitan dengan Kebiasaan, dan Yurisprudensi. Adapun sumber utama hukum perusahaan adalah KUHD. ${ }^{1}$

\footnotetext{
${ }^{1}$ Ni Made Pratiwi, 2017, “Hubungan Hukum Perusahaan Induk Berbentuk Perseroan Terbatas Dengan Anak Perusahaan Berbentuk Persekutuan Komanditer", Acta Comitas, Vol.02, no.01, April 2017, h. 66. https://ojs.unud.ac.id/index.php/ActaComitas/article/view/34258/20614 diakses tanggal 28 Januari 2019 pukul 22.23
} 
Bahwa perlindungan terhadap tenaga kerja dimaksudkan untuk menjamin hak-hak dasar pekerja / buruh dan menjamin kesamaan kesempatan serta perlakuan tanpa diskriminasi atas dasar apapun untuk mewujudkan kesejahteraan pekerja/buruh dan keluarganya dengan tetap memperhatikan perkembangan dunia usaha. Saat ini kaum buruh sering dikesampingkan dalam pembuatan kebijakan. Termasuk dalam kebijakan upah dan sejenisnya, karena buruh masih dianggap sebagai komunitas lemah pendidikan dan lemah segala bidang. ${ }^{2}$ Sulitnya mencari pekerjaan baru, menimbulkan situasi yang tidak enak karena harus menganggur. ${ }^{3}$

Kesepakatan dalam pengolahan dipandang sebagai suatu kerja sama antara perusahaan dan buruh. ${ }^{4}$ Secara umum upah adalah pembayaran yang diterima buruh selama ia melakukan pekerjaan atau dipandang melakukan pekerjaan. ${ }^{5}$ Perihal isi ketentuan dalam batang tubuh yang ada relevansinya dengan masalah ketenagakerjaan, terutama ditentukan pada Undang-Undang Dasar 1945 pasal 27 ayat (2), yang menentukan bahwa "tiap-tiap warga Negara berhak atas pekerjaan dan penghidupan yang layak bagi kemanusiaan". ${ }^{6}$ Dalam berbagai tulisan tentang pemburuhan seringkali dijumpai adagium yang berbunyi "pekerja/buruh adalah tulang punggung perusahaan". Adagium ini nampaknya biasa aja, seperti tidak mempunyai makna. Tetapi kalu dikaji lebih jauh akan kelihatan kebenarannya. Pekerja dikatakan sebagai tulang punggung, karena dia memang mempunyai peranan yang penting. ${ }^{7}$

Menurut pasal 90 ayat (1) UU No. 13 tahun 2003 tentang Ketenagakerjaan ( UU ketenagakerjaan) pengusaha dilarang membayar upah lebih rendah dari upah minimum, baik upah minimum (UM) berdasarkan wilayah provinsi dan kabupaten kota ( yang sering disebut upah minimum regional/UMR) maupun upah minimum berdasarkan sector pada wilayah provinsi atau kabupaten/kota ( upah minimum sektoral/UMS).

Dalam pasal 90 Undang-Undang Nomor 13 Tahun 2003 Tentang Ketenagakerjaan disebutkan bahwa :

1. Pengusaha dilarang membayar upah lebih rendah dari upah minimum sebagaimana dimaksud dalam pasal 89.

2. Bagi pengusaha yang tidak mampu membayar upah minimum sebagaimana dimaksud dalam pasal 89 dapat dilakukan penangguhan.

\footnotetext{
${ }^{2}$ Moh Syaufi Syamsudin, menciptakan hubungan kerja yang islami ditempat kerja, Jakarta:Swara Bumi,2003,h.17

${ }^{3}$ Ari Hernawan, 2016, “Keberadaan Uang Pesangon Dalam Pemutusan Hubungan Kerja Demi Hukum Di Perusahaan Yang Sudah Menyelenggarakan Program Jaminan Pensiun”, Kertha Patrika, Vol.38 ,no.01, April 2016, h. 1. https://ojs.unud.ac.id/index.php/kerthapatrika/article/view/21530 diakses tanggal 28 Januari 2019 pukul 22.30

${ }^{4}$ Afzalur Rahman, Doktrin Ekonomi Islam, Jakarta:Dana Bakti Wakaf,1995,h.341

${ }^{5}$ Muwartie B Raharjo,Upah dan Kebutuhan Hidup Buruh dalam Analisis CSIS Vol.22,no.26,1993,h.214

${ }^{6}$ Djumadi, Hukum Perburuhan Perjanjian Kerja, Jakarta:Rajawali Pers,2008, h.1-2.

${ }^{7}$ H.Zainal Asikin dkk, Dasar-dasar Hukum Pemburuhan, Jakarta: Rajawali Pers, 2010, h. 95.
} 
3. Tata cara penangguhan sebagaimana dimaksud pasal 89 dalam ayat (2) diatur dengan keputusan Menteri.

\subsection{Rumusan Masalah}

Berdasarkan latar belakang tersebut diatas, maka dirumuskan lah 2 (dua) pokok permasalahan sebagai berikut :

1. Apa yang menjadi standar dalam memberikan upah minimum kepada pekerja kontrak pada Rumah Sakit Umum Daerah Wangaya Kota Denpasar

2. Bagaimana pelaksanaan sistem kerja terhadap pekerja kontrak pada Rumah Sakit Umum Daerah Wangaya Kota Denpasar

\subsection{Tujuan Penulisan}

1. Untuk mengkaji sistem pekerja kontrak pada Rumah Sakit Umum Daerah Wangaya

2. Untuk menggali peraturan perundang-undangan di Rumah Sakit Umum Daerah Wangaya sudah sesuai dengan Peraturan Pusat

\section{Isi Makalah}

\subsection{Metode}

Metode penelitian ini yang digunakan dalam penulisan skripsi ini adalah penelitian hukum dalam aspek hukum empiris. Hukum ini ditujukan sebagai suatu prinsip yang diamati di dalam kehidupan nyata atau yang benar-benar dirasakan, dialami secara nyata dengan interpretasi peneliti. Metode penelitian hukum empiris adalah suatu metode penelitian hukum yang berfungsi dalam artian nyata dan meliti bagaimana bekerjanya hukum di dalam masyarakat.

\subsection{Hasil dan Analisis}

2.2.1 Apa yang menjadi standar dalam memberikan upah minimum kepada pekerja kontrak pada Rumah Sakit Umum Daerah Wangaya Kota Denpasar

Standar yang dipakai dalam memberikan upah terhadap pekerja itu secara umum mempunyai peraturan perundang-undangan dimana peraturan tersebut sudah menjadi peraturan yang sangat lumrah dalam bidang hukum mengenai pengupahan dan ketenagakerjaan, yaitu :

a. Undang-Undang No 13 Tahun 2003 Tentang Ketenagakerjaan

b. Peraturan Pemerintah Republik Indonesia No 78 Tahun 2015 Tentang Pengupahan

c. Peraturan Menteri Tenaga Kerja dan Transmigrasi No 7 Tahun 2013 Tentang Upah Minimum

1. Upah Minimum hanya berlaku bagi pekerja/buruh yang mempunyai masa kerja kurang dari 1 (satu) tahun 
d. Peraturan Menteri Ketenagakerjaan Republik Indonesia No 1 Tahun 2017 Tentang Struktur dan Skala Upah

Jenis pelayanan diatas merupakan sumber yang melingkupi dengan berlakunya standar dalam memberikan upah minimum terhadap pekerja kontrak. Berdasarkan wawancara dengan Ni Putu Ari Purbasari, S.H dengan jabatan pelaksana dan Dra. Anak Agung Ayu Tisna Herawati sebagai penanggungjawab dengan Jabatan Kepala Sub. Bagian Kepegawaian pada Bagian Umum Rumah Sakit Umum Daerah Wangaya Kota Denpasar, hasil dari wawancara itu sebagai berikut ada berbagai macam jenis Pekerja Kontrak dari golongan I sampai golongan III. standar dalam memberikan upah terhadap pekerja kontrak di Rumah Sakit Umum Wangaya Denpasar sesuai dengan Keputusan Direktur Rumah Sakit Umum Daerah Wangaya Kota Denpasar Tahun 2016, dengan nomor : 188.45/14/RSUDW/2016 Tentang Penetapan Gaji Pegawai Non Pegawai Negeri Sipil (PNS) Pada Rumah Sakit Umum Daerah Wangaya Kota Denpasar Tahun 2016. Disini ada beberapa peraturan perundang-undangan yang mengatur tentang Penetapan Gaji Pegawai Non Pegawai Negeri Sipil (PNS) berdasarkan Keputusan Direktur Rumah Sakit Umum Daerah Wangaya Kota Denpasar

a. Bahwa dalam rangka meningkatkan kesejahteraan Pegawai Negeri Sipil pada Rumah Sakit Umum Daerah Wangaya Kota Denpasar perlu menetapkan gaji pegawai sesuai dengan Upah minimum.

b. Berdasarkan Peraturan Gubernur Bali Nomor 1 Tahun 2016 tentang Upah Minimum Kabupaten/Kota.

c. Bahwa sesuai dengan pasal 9 Peraturan Walikota Denpasar tentang Pedoman Pengangkatan dan Pemberhentian Pejabat Pengelola dan Pegawai Non Pegawai Negeri Sipil pada RS.

d. Bahwa berdasarkan pertimbangan sebagaimana dimaksud huruf $\mathrm{a}, \mathrm{b}$ dan huruf c perlu menetapkan Keputusan Direktur tentang Penetapan Gaji Pegawai Non Pegawai Negeri Sipil (PNS) pada Rumah Sakit Umum Daerah Wangaya Kota Denpasar Tahun 2016.

e. Undang-Undang Nomor 5 Tahun 2014 tentang Aparatur Sipil Negara (Lembaran Negara Republik Indonesia Tahun 2014 Nomor 16, Tambahan Lembaran Negara Republik Indonesia Nomor 5994)

f. Peraturan Pemerintah Republik Indonesia Nomor 53 Tahun 2010 tentang Disiplin Pegawai Negeri Sipil (Lembaran Negara Republik Indonesia Tahun 2010 Tahun 74, Tambahan Lembaran Negara Republik Indonesia Nomor 5135)

g. Peraturan Gubernur Bali Nomor 1 Tahun 2016 tentang Upah Minimum Kabupaten/Kota (Berita Daerah Provinsi Bali Tahun 2016 Nomor 1)

h. Peraturan Walikota Denpasar Tanggal 8 Oktiber 2012 Nomor 33 Tahun 2012 tentang Tata Kelola Rumah Sakit Umum Daerah Wangaya Kota Denpasar (Berita Daerah Kota Denpasar Tahun 2012 Nomor 33) 
i. Peraturan Walikota Denpasar Nomor 4 Tahun 2014 tentang Pedoman Pengangkatan dan Pemberhentian Pejabat Pengelola dan Pegawai Non Pegawai Negeri Sipil Pada Rumah Sakit Umum daerah Wangaya Kota Denpasar (Berita Daerah Kota Denpasar Tahun 2014 Nomor 4).

Pemutusan yang ditetapkan sebagai keputusan Direktur Rumah Sakit Umum Wangaya Denpasar tentang Penetapan Gaji Pegawai Non Pegawai Negeri Sipil (PNS) Pada Rumah Sakit Umum Wangaya Denpasar tahun 2016

1. Menetapkan Gaji Pegawai Non Pegawai Negeri Sipil (PNS) pada Rumah Sakit Umum daerah wangaya Kota Denpasar Tahun 2016

2. Gaji Pegawai Non pegawai Negeri sipil (PNS) dimaksud dictum Kesatu sebagaimana tercantum dalam lampiran keputusan ini

3. Segala biaya yang timbul sebagai akibat ditetapkannya keputusan ini dibebankan kepada Belanja Oprasional Rumah sakit Umum Daerah Wangaya Kota Denpasar

Dari hasil wawancara mengenai standar dalam memberikan upah minimum terhadap pekerja kontrak di Rumah Sakit Umum Daerah Wangaya Kota Denpasar, dimana standar tersebut mengacu kepada Keputusan Direktur Rumah Sakit Umum Daerah Wangaya Kota Denpasar Nomor 188.45/14/RSUDW/2016 Tentang Penetapan Gaji Pegawai Non Pegawai Negeri Sipil (PNS) Pada Rumah Sakit Umum Daerah Wangaya kota Denpasar Tahun 2016 (wawancara, 27 juli 2018).

\subsubsection{Bagaimana pelaksanaan sistem kerja terhadap pekerja kontrak pada Rumah Sakit Umum Daerah Wangaya Kota Denpasar}

Berdasarkan pasal 15 ayat (2) keputusan Menteri Peraturan Menteri Tenaga Kerja dan Transmigrasi Nomor 7 Tahun 2013 Tentang Upah Minimum disebutkan Upah Minimum hanya berlaku bagi pekerja/buruh yang mempunyai masa kerja kurang dari 1 (satu) tahun dalam peraturan perundang-undangan yang berlaku.

Pengaturan Upah Minimum bagi pekerja kontrak pun diatur secara tegas dalam Peraturan Menteri Tenaga Kerja Nomor : PER-01/MEN/1999 jo. Keeputusan Menteri Tenaga Kerja dan Transmigrasi Nomor : KEP226/MEN/2000, pasal 14 ayat (1), bahwa upah minimum berlaku untuk semua status pekerja, baik tetap, tidak tetap, maupun percobaan

Pengertian upah minimum menurut pasal 1 angka 1 Peraturan Menteri Tenaga Kerja Nomor : PER-01/MEN/1999 tentang Upah Minimum adalah upah bulanan terendah yang terdiri dari upah pokok termasuk tunjangan tetap. Berdasarkan pasal 89 ayat (1) Undang-Undang Nomor 13 Tahun 2003 Tentang Ketenagakerjaan, Upah Minimum terdiri atas :

a. Upah Minimum berdasarkan wilayah provinsi atau kabupaten/kota 
b. Upah Minimum berdasarkan sektor pada wilayah provinsi atau kabupaten/kota

Pelaksanaan Upah Minimum Kabupaten/Kota (UMK) ini di Kota Denpasar khususnya di RSUD Wangaya Denpasar berdasarkan Peraturan Gubernur Bali Nomor 65 tahun 2017 tentang Upah Minimum Kabupaten/Kota untuk tahun 2018 adalah sebesar Rp. 2.363.000,00.

Berdasarkan wawancara dengan Ni Putu Ari Purbasari, S.H dengan Jabatan Pelaksana serta Dra. Anak Agung Ayu Tisna Herawati sebagai Penanggungjawab dengan Jabatan Kepala Sub Bagian Kepegawaian pada Bagian Umum Rumah Sakit Umum Daerah Wangaya Kota Denpasar Wajib Mengikuti ketentuan UMK Wilayah Kota Denpasar yaitu sebesar Rp. 2.363.000,00 untuk tahun 2018 yang telah diatur dalam Peraturan Gubernur Bali Nomor 65 tahun 2017 tentang Upah Minimum. Berdasarkan hasil wawancara Ni Putu Ari Purbasari S.H dengan Jabatan Sebagai Pelaksana untuk gaji pegawai non pegawai negeri sipil (PNS) itu berdasarkan golongan pendidikan terakhir dan profesi. Menurut Lampiran Keputusan Direktur Rumah Sakit Umum Daerah Wangaya Kota Denpasar tanggal 4 januari 2016 Nomor : 188.45/14/RSUDW/2016 tentang Penetapan Gaji Pegawai Non Pegawai Negeri Sipil (PNS) Pada Rumah Sakit Umum Daerah Wangaya Kota Denpasar Tahun 2016 itu ada pendidikan terakhir SD-SLTP untuk golongan I, SLTA-D3 untuk Golongan II, D4S1/Profesi untuk Golongan III, Dokter Umum, Dokter Gigi, Dokter Spesialis untuk Golongan III dan Golongan IV. Menurut Surat Perjanjian Kerja Pegawai Non PNS Nomor : 36/PK/I/2018 pasal 3 tentang Hak dan Kewajiban. Pasal 3 ayat (1) Pihak Pertama memiliki hak dan kewajiban sebagai berikut :

Pihak Pertama memiliki hak dan kewajiban sebagai berikut :

1. Berhak untuk memanfaatkan tenaga, ketrampilan dan pengetahuan yang dimiliki Pihak Kedua untuk melaksanakan pekerjaan di lingkungan Rumah Sakit Umum Daerah Wangaya Kota Denpasar

2. Berkewajiban :

a. Memberikan imbalan berupa gaji/honor atas pekerjaan yang telah dilakukan oleh Pihak Kedua

b. Memberikan bimbingan serta memberikan peluang untuk memberikan meningkatkan kemampuannya untuk kepentingan pekerjaan yang dilakukannya

c. Menyediakan alat pelindung diri sesuai dengan persyaratan keselamatan dan kesehatan kerja (K3)

d. Memberikan jasa pelayanan sesuai dengan ketentuan yang telah di tetapkan

Pihak Kedua memiliki hak dan kewajiban sebagai berikut :

1. Berhak Untuk : 
a. Mendapatkan Gaji/Honor sebesar Rp. 1.926.000,- (satu juta Sembilan ratus dua puluh enam ribu rupiah) setiap bulan dan dibayarkan pada awal bulan berikutnya

b. Memperoleh jasa pelayanan, insentif dan bantuan pakaian disesuaikan dengan kemampuan serta diatur berdasarkan keputusan direktur Rumah Sakit Umum Daerah Wangaya Kota Denpasar

c. Cuti diberikan sesuai dengan keputusan Direktur Rumah Sakit Umum Daerah Wangaya Kota Denpasar Nomor 188.45/301/RSUDW/2014 tanggal 19 Desember 2014

d. Memperoleh fasilitas keselamatan dan kesehatan kerja (K3RS)

2. Berkewajiban Untuk :

a. Melaksanakan tugas-tugas yang diberikan oleh Pihak Pertama

b. Menaati semua peraturan dan tata tertib pada Rumah Sakit Umum Daerah Wangaya Kota Denpasar

c. Wajib meningkatkan kemampuan dan ketrampilan dalam rangka pelaksanaan tugas-tugasnya

d. Menjaga etika, harkat dan martabat Rumah Sakit Umum Daerah Wangaya Kota Denpasar (wawancara, 5 agustus 2018).

Berdasarkan Peraturan Menteri Tenaga Kerja dan Transmigrasi Nomor 7 Tahun 2013 Tentang Upah Minimum, menyatakan Pasal 15 ayat (2) disebutkan bahwa Upah Minimum hanya berlaku bagi pekerja/buruh yang mempunyai masa kerja kurang dari 1 (satu) tahun serta Peraturan Walikota Denpasar Nomor 4 Tahun 2014 Tentang Pedoman Pengangkatan dan Pemberhentian Pejabat Pengelola dan Pegawai Non Pegawai Negeri Sipil Pada Rumah Sakit Umum Daerah Wangaya Denpasar dimana pasal 1 nomor 13 yang menyebutkan " penilaian kinerja pegawai non PNS adalah penilaian hasil pelaksanaan pekerjaan dalam jangka waktu 1 (satu) tahun yang ditandatangani oleh Pejabat Keuangan dan Pejabat Teknis selaku Pejabat Penilai dan Direktur selaku atasan Pejabat Penilai " pasal 7 nomor 2 (dua) yang menyebutkan " Pegawai Non PNS yang diangkat dengan status pegawai tetap dilakukan melalui masa percobaan calon pegawai selama 1 (satu) tahun sesuai dengan formasi yang tersedia " serta pasal 7 nomor 3 (tiga) menyebutkan pegawai Non PNS yang diangkat dengan status kontrak untuk jangka waktu 1 (satu) tahun dan dapat diperpanjang sesuai formasi yang tersedia dan dapat diperpanjang untuk jangka waktu satu tahun berikutnya “. Berdasarkan wawancara Ni Putu Ari Purbasari, S.H dengan Jabatan Pelaksana serta Dra. Anak Agung Ayu Tisna Herawati dengan Jabatan Kepala Sub. Bagian Kepegawaian pada Bagian Umum Rumah Sakit Umum Daerah Wangaya Kota Denpasar, yang tercantum dari Surat Perjanjian Kerja Pegawai Non PNS Nomor : 36/PK/I/2018 Pasal 5 Tentang 
Jangka Waktu Nomor 3 itu menyebutkan bahwa setelah memasuki masa kerja 2 (dua) tahun dengan kinerja baik dapat ditetapkan sebagai pegawai tetap Non Pegawai Negeri Sipil (PNS). Dari hasil wawancara dengan Ni Putu Ari Purbasari, S.H dengan Jabatan sebagai Pelaksana serta Dra. Anak Agung Ayu Tisna Herawati dengan Jabatan sebagai Kepala Sub. Bagian Kepegawaian pada Bagian Umum Rumah Sakit Umum Daerah Wangaya Kota Denpasar, mengikuti sebagaimana telah dilampirkan sesuai dengan Keputusan Direktur Rumah Sakit Umum Daerah Wangaya Kota Denpasar Nomor : 188.45/14/RSUDW/2016 Tentang Penetapan Gaji Pegawai Non Pegawai Negeri Sipil (PNS) Pada Rumah Sakit Umum Daerah Wangaya Kota Denpasar bahwa kenaikan Upah itu setiap 2 tahun dari masa kerja hingga masa akhir kerja tergantung pendidikan terakhir sesuai dengan golongan, golongan I SD-SLTP, golongan II SLTA-D3, golongan III D4-S1/Profesi dan golongan IV Dokter Umum, Dokter Gigi, Dokter Spesialis (wawancara, 15 agustus 2018).

Dari hasil wawancara mengenai Pelaksanaan Kontrak Kerja dengan Upah Minimum terhadap Pekerja Kontrak dengan Pihak Rumah Sakit Umum Daerah Wangaya Kota Denpasar, masih terjadi kesenjangan antara ketentuan norma dengan fakta.

Menurut Ni Putu Paramitha Dewi, S.S sebagai admin poliklinik psikiatri, Rumah Sakit Umum Wangaya tidak melakukan kenaikan gaji dalam per-satu tahun (seperti biasanya), dikarenakan menurut Keputusan Direktur Rumah Sakit Umum Daerah Wangaya Kota Denpasar Nomor : 188.45/14/RSUDW/2016 Tentang Penetapan Gaji Pegawai Non Pegawai Negeri Sipil (PNS) Pada Rumah Sakit Umum Daerah Wangaya Kota Denpasar Tahun 2016 kenaikan gaji di setiap masing-masing golongan dan berdasarkan profesi itu setiap 2 (dua) tahun. Berdasarkan keterangan tersebut nampak ada faktor yang tidak sesuai antara norma yang tertulis dengan kenyataan yang ada (wawancara 2 september 2018)

Menurut Tude Trisnajaya S.H,M.H sebagai staff hukum dan hubungan masyarakat di Rumah Sakit Umum Daerah Wangaya Kota Denpasar, perjanjian kerja yang diberikan disepakatinya karena hanya ingin mencari pengalaman bekerja setelah lulus kuliah untuk menerapkan ilmu yang didapatnya, sehingga enggan untuk menanyakan masalah peraturan kenaikan gaji per-satu tahun dimana peraturan tersebut diatur dalam Peraturan Menteri Tenaga Kerja dan Transmigrasi No. 7 Tahun 2013 Tentang Upah Minimum dimana pasal 15 ayat (2) yang menyebutkan “ Upah Minimum hanya berlaku bagi pekerja/buruh yang mempunyai masa kerja kurang dari 1 (satu) tahun " dan Peraturan Walikota Denpasar Nomor 4 Tahun 2014 Tentang Pedoman Pengangkatan dan Pemberhentian Pejabat Pengelola dan Pegawai Non Pegawai Negeri Sipil Pada Rumah Sakit Umum Daerah Wangaya Denpasar dimana pasal 1 nomor 13 yang menyebutkan " penilaian kinerja pegawai non PNS adalah penilaian hasil pelaksanaan pekerjaan dalam jangka waktu 1 (satu) tahun yang ditandatangani oleh Pejabat Keuangan dan Pejabat Teknis selaku Pejabat Penilai dan Direktur selaku atasan Pejabat Penilai " pasal 7 nomor 2 (dua) yang menyebutkan " Pegawai Non PNS yang diangkat dengan status pegawai tetap dilakukan 
melalui masa percobaan calon pegawai selama 1 (satu) tahun sesuai dengan formasi yang tersedia " serta pasal 7 nomor 3 (tiga) menyebutkan pegawai Non PNS yang diangkat dengan status kontrak untuk jangka waktu 1 (satu) tahun dan dapat diperpanjang sesuai formasi yang tersedia dan dapat diperpanjang untuk jangka waktu satu tahun berikutnya " (wawancara, 3 september 2018)

Pelaksanaan upah minimum terhadap pekerja kontrak di Rumah Sakit Umum Daerah Wangaya Kota Denpasar, RSUD Wangaya tunduk terhadap Keputusan Direktur Rumah Sakit Umum Daerah Wangaya kota Denpasar Nomor : 188.45/14/RSUDW/2016 Tentang Penetapan Gaji Pegawai Non Pegawai Negeri Sipil (PNS) Pada Rumah Sakit Umum Daerah Wangaya Kota Denpasar, sedangkan tidak mematuhi Peraturan Menteri Tenaga Kerja dan Transmigrasi Nomor 7 Tahun 2013 Tentang Upah Minimum serta Peraturan Walikota Denpasar Nomor 4 Tahun 2014 Tentang Pedoman Pengangkatan dan Pemberhentian Pejabat pengelola dan Pegawai Non Pegawai Negeri Sipil Pada Rumah Sakit Umum Daerah Wangaya Denpasar.

Peraturan perundang-undangan sebagaimana dimaksud dalam pasal 7 ayat (1) UU No 12 Tahun 2011 mencakup peraturan yang ditetapkan oleh majelis permusyawaratan rakyat, Dewan Perwakilan Rakyat, Dewan Perwakilan Daerah, Mahkamah Agung, Mahkamah Konstitusi, Badan Pemeriksa Keuangan, Komisi Yudisial, Bank Indonesia, Menteri, Badan, Lembaga yang setingkat yang dibentuk dengan Undang-Undang atau Pemerintah atas perintah Undang-Undang, Dewan Perwakilan Rakyat Daerah Kabupaten/Kota, Bupati/Walikota, Kepala Desa atau yang setingkat. Mengenai kekuatan mengikat Peraturan/Kebijakan dibawah Peraturan Menteri sebagai Peraturan Kebijakan yang bukan Peraturan Perundang-undangan, Peraturan Kebijakan tidak secara langsung mengikat secara hukum tetapi mengandung relevansi hukum. Peraturan Kebijakan pada dasarnya ditujukan kepada badan atau pejabat administrasi Negara sendiri. Jadi yang pertama melaksanakan ketentuan yang termuat dalam peraturan kebijakan adalah badan atau pejabat administrasi Negara sendiri. Tetapi ketentuan tersebut secara tidak langsung akan dapat mengenai masyarakat umum. Kedudukan Peraturan Menteri bukan tidak diatur sama sekali. Dalam pasal 7 ayat (4) RUU PPP ditegaskan bahwa jenis peraturan perundang-undangan, selain yang dapat dalam hierarki tetap diakui keberadaannya dan mempunyai hukum mengikat. Pemerintah mengusulkan penambahan satu ayat di dalam pasal 7 yang ada pada intinya menyatakan bahwa peraturan menteri mempunyai hierarki diantara Peraturan Presiden dan Peraturan Daerah. Kalau terjadi benturan antara Peraturan Menteri dengan Peraturan Daerah tidak harus diuji dengan hierarki, tetapi bisa juga diuji lewat pengujian substansinya di Mahkamah Agung.

Secara hierarki dalam Undang-Undang Nomor 12 Tahun 2011 Tentang Pembentukan Peraturan Perundang-undangan Bab III Jenis, Hierarki, Dan Materi Muatan peraturan Perundang-undangan pasal 7 menyebutkan : 
(1) Jenis dan hierarki Peraturan Perundang-undangan terdiri atas:
a. Undang-Undang Dasar Negara Republik Indonesia Tahun 1945
b. Ketetapan Majelis Permusyawaratan Rakyat
c. Undang-Undang/Peraturan Pemerintah Pengganti Undang-Undang
d. Peraturan Pemerintah
e. Peraturan Presiden
f. Peraturan Daerah Provinsi; dan
g. Peraturan Kabupaten/Kota

(2) Kekuatan hukum Peraturan Perundang-undangan sesuai dengan hierarki sebagaimana dimaksud pada ayat (1).

Mengenai pelaksanaan upah minimum terhadap pekerja kontrak di Rumah Sakit umum Daerah Wangaya Kota Denpasar, alasan Rumah Sakit Umum Daerah Wangaya Kota Denpasar mengikuti Keputusan Direktur Rumah Sakit Umum Daerah Wangaya Kota Denpasar Nomor : 188.45/14/RSUDW/2016 Tentang Penetapan Gaji Pegawai Non Pegawai Negeri Sipil (PNS) Pada Rumah Sakit Umum Daerah Wangaya Kota Denpasar bahwa Keputusan Direktur adalah kebijakan di Rumah Sakit, setiap keputusan yang diambil dari Direktur pasti sudah sesuai dengan Peraturan Perundang-undangan seperti Peraturan Walikota, Peraturan Daerah, Peraturan Gubernur, Peraturan Menteri, dll dan secara hierarki Keputusan Direktur berada dibawah Peraturan Walikota.

\section{Penutup}

\subsection{Simpulan}

1. Yang menjadi standar dalam memberikan upah minimum kepada pekerja kontrak pada Rumah Sakit Umum Daerah Wangaya Kota Denpasar mengikuti Keputusan Direktur Rumah Sakit Umum Daerah Wangaya Kota Denpasar Nomor : 188.45/14/RSUDW/2016 Tentang Penetapan Gaji Pegawai Non Pegawai Negeri Sipil (PNS) Pada Rumah Sakit Umum Daerah Wangaya Kota Denpasar Tahun 2016 dimana ada pendidikan terakhir SD-SLTP untuk golongan I, SLTA-D3 untuk golongan II, D4-S1/Profesi untuk golongan III, Dokter Umum, Dokter Gigi, Dokter Spesialis untuk golongan III dan golongan IV

2. Pelaksanaan upah minimum terhadap pekerja kontrak pada Rumah Sakit Umum Daerah Wangaya Kota Denpasar tidak sesuai dengan Pasal 15 ayat (2) Peraturan Menteri Tenaga Kerja dan Transmigrasi Nomor 7 Tahun 2013 tentang Upah Minimum yang menyebutkan bahwa " Upah Minimum hanya berlaku bagi pekerja/buruh yang mempunyai masa kerja kurang dari 1 (satu) tahun. " dan Peraturan Walikota Denpasar Nomor 4 Tahun 2014 Tentang Pedoman Pengangkatan dan Pemberhentian Pejabat Pengelola Dan Pegawai Non Pegawai Negeri Sipil Pada Rumah Sakit Umum Daerah Wangaya Denpasar Bab I Ketentuan Umum pasal 1 
Nomor 13 menyebutkan "Penilaian Kinerja Pegawai Non PNS adalah Penilaian hasil pelaksanaan pekerjaan dalam jangka waktu 1 (satu) tahun yang ditandatangani oleh Pejabat Keuangan dan Pejabat Teknis selaku Pejabat Penilaian dan Direktur selaku atasan Pejabat Penilai " pasal 7 nomor 2 (dua) yang menyebutkan " Pegawai Non PNS yang diangkat dengan status pegawai tetap dilakukan melalui masa percobaan calon pegawai selama 1 (satu) tahun sesuai dengan formasi yang tersedia " serta pasal 7 nomor 3 (tiga) menyebutkan pegawai Non PNS yang diangkat dengan status kontrak untuk jangka waktu 1 (satu) tahun dan dapat diperpanjang sesuai formasi yang tersedia dan dapat diperpanjang untuk jangka waktu satu tahun berikutnya ". Sedangkan Surat Perjanjian Kerja Pegawai Non PNS Nomor : 36/PK/1/2018 pasal 5 nomor 2 (dua) tentang jangka waktu menyebutkan " setelah memasuki masa kerja 2 (dua) tahun dengan kinerja baik dapat ditetapkan sebagai pegawai tetap non pegawai negeri sipil (PNS) “.

\subsection{Saran}

1. Rumah Sakit Umum Daerah Wangaya Kota Denpasar harus lebih mematuhi Peraturan yang ada di pusat, agar tidak terjadi kesenjangan dimana aturan hukum dengan fakta tidak berbeda.

2. Dinas Tenaga Kerja, Transmigrasi dan Kependudukan Provinsi Bali sebagai dinas yang berhak melakukan pengawasan dalam bidang Ketenagakerjaan harus lebih sering melakukan pemeriksaan secara berkala mengenai peraturan-peraturan Ketenagakerjaan di masing-masing Perkantoran/Perushaan Negeri maupun Swasta serta perlu adanya sosialisasi kepada para staff Rumah Sakit agar semuanya sesuai dengan sebagaimana peraturan perundang-undangan berjalan sesuai gimana semestinya. 


\section{DAFTAR PUSTAKA}

\section{BUKU}

Moh Syaufi Syamsudin, menciptakan hubungan kerja yang islami ditempat kerja,Jakarta:Swara Bumi,2003

Afzalur Rahman, Doktrin Ekonomi Islam, Jakarta:Dana Bakti Wakaf, 1995

Muwartie B Raharjo, Upah dan Kebutuhan Hidup Buruh dalam Analisis CSIS Vol.22,no.26,1993

Djumadi, Hukum Perburuhan Perjanjian Kerja , Jakarta:Rajawali Pers, 2008

H.Zainal Asikin dkk, Dasar-dasar Hukum Pemburuhan, Jakarta: Rajawali Pers, 2010

\section{JURNAL}

Ni Made Pratiwi, 2017, "Hubungan Hukum Perusahaan Induk Berbentuk Perseroan Terbatas Dengan Anak Perusahaan Berbentuk Persekutuan Komanditer", Acta Comitas, Vol.02, no.01, April 2017, h. 66. https://ojs.unud.ac.id/index.php/ActaComitas/article/view/34258/20614 diakses tanggal 28 Januari 2019 pukul 22.23

Ari Hernawan, 2016, "Keberadaan Uang Pesangon Dalam Pemutusan Hubungan Kerja Demi Hukum Di Perusahaan Yang Sudah Menyelenggarakan Program Jaminan Pensiun", Kertha Patrika, Vol.38 ,no.01, April 2016, $\quad$ h. 1 . https://ojs.unud.ac.id/index.php/kerthapatrika/article/view/21530 diakses tanggal 28 Januari 2019 pukul 22.30

\section{PERUNDANG-UNDANGAN}

Undang-Undang No. 13 Tahun 2003 Tentang Ketenagakerjaan

Peraturan Menteri Tenaga Kerja dan Transmigrasi No. 7 Tahun 2013 Tentang Upah Minimum

Peraturan Walikota Denpasar No. 4 Tahun 2014 Tentang Pedoman Pengangkatan dan Pemberhentian Pejabat Pengelola dan Pegawai Non Pegawai Negeri Sipil Pada Rumah Sakit Umum Daerah Wangaya Kota Denpasar 
